Jurnal Arsitektur dan Perencanaan (JUARA)

Hal. 139-152: ISSN Online: 2620-9896

Vol 3, No 2 (2020): September (Jurnal Arsitektur dan Perencanaan

\title{
PENATAAN LINGKUNGAN KAMPUS UNTUK PENGKONDISIAN KECEPATAN ANGIN (KASUS: KAMPUS 1 UNISA YOGYAKARTA)
}

\section{Riri Chairiyah}

Universitas Aisyiyah Yogyakarta. +6285721121894

Email: ririchairiyah@unisayogya.ac.id

\begin{abstract}
INFORMASI ARTIKEL
Abstract: Buildings that are used as public spaces must fulfill the proper functioning of the building. Facilities are one aspect of functional feasibility. User convenience in campus buildings is needed to increase. Because every year, number of students increases quite high. One aspect of comfort is the user's psychological sense of wind speed. Wind speed that is too high or tool low can make uncomfortable effect on the user. The dominant wind speed is felt in the environment, where the environment between campus buildings is an important area for the mobility of regional users. The purpose of this research is to arrange the environment between campus buildings using the literature study method. Exploring environmental problems is assisted by ENVI-met software. The research results are in the form of structuring the campus environment to reduce high wind speeds, which can be done on architecture and landscape elements. Arrangement of architectural elements, namely the use of shade / canopy, use of perforated fences, use of horizontal fins on building facades and use of platforms in tall buildings. Meanwhile, the arrangement of landscape elements is the selection of vegetation, especially tree species with tight leaves. Minimum vegetation $2 \mathrm{~m}$ high with a less dense stacking pattern. Vegetation can be placed in areas where there are winds and bumpy or contoured land surfaces.
\end{abstract}

Keywords: Architectural Arrangement, Landscape Arrangement, Wind Speed

\begin{abstract}
Abstrak: Bangunan yang digunakan sebagai ruang public harus memenuhi kelaikan fungsi bangunan. Kenyamanan adalah salah satu aspek kelaikan fungsi. Yang mana kenyamanan pengguna di bangunan kampus semakin penting dikarenakan peningkatan jumlah mahasiswa setiap tahun cukup tinggi. Salah satu aspek kenyamanan adalah psikologis pengguna terhadap kecepatan angin yang dirasakan pengguna. Kecepatan angin yang terlalu tinggi atau terlalu rendah dapat memberikan efek tidak nyaman bagi pengguna. Kecepatan angin dominan dirasakan di area lingkungan luar, dimana lingkungan antar bangunan kampus menjadi area penting sebagai area mobilitas pengguna. Tujuan dari penelitian ini adalah penataan lingkungan antar bangunan kampus dengan menggunakan metode studi literatur. Penggalian permasalahan lingkungan dibantu oleh software ENVI-met. Adapun hasil penelitian berupa penataan lingkungan kampus untuk menurunkan kecepatan angin yang tinggi, yang dapat dilakukan pada emelen arsitektur dan elemen lansekap. Penataan elemen arsitektur yaitu penggunaan naungan/kanopi, penggunaan pagar berlubang, penggunaan sirip-sirip horizontal pada fasad bangunan dan penggunaan platform pada bangunan tinggi. Sedangkan penataan elemen lansekap yaitu pemilihan vegetasi khususnya jenis pohon berdaun rapat. Vegetasi minimal tinggi $2 \mathrm{~m}$ dengan pola susun yang tidak terlalu rapat. Vegetasi dapat diletakan di area datangnya angin serta permukaan tanah dibuat bergelombang atau berkontur.
\end{abstract}

Kata Kunci: Penataan Arsitektur, Penataan Lansekap, Kecepatan Angin

Article history:

Received; 2020-09-10

Revised; 2020-09-15

Accepted; 2020-09-24

\section{PENDAHULUAN}

Tahun 2018 jumlah mahasiswa mencapai kurang lebih 7,7 juta jiwa (PDDikti, 2018). Sementaran peningkatan jumlah mahasiswa di Indonesia setiap tahun akan terus naik. Hal tersebut menyebabkan kampus harus 
meningkatkan persiapan sarana belajar, salah satunya adalah sarana fasilitas kampus. Sarana fasilitas kampus menjadi bagian yang langsung dirasakan oleh pengguna kampus saat berkegiatan. Pengguna kampus akan mengalami sejumlah pengalaman kenyamanan, kesehatan, keselamatan serta keamanan saat menggunakan fasilitas kampus. Keempat aspek tersebut juga menjadi sebuah standar bagi bangunan di Indonesia untuk dikatakan layak fungsi (Permen PU., 2007). Salah satu aspek laik fungsi yaitu kenyamanan menjadi aspek yang mampu meningkatkan kualitas fasilitas kampus.

Kenyamanan pada fasilitas kampus tidak hanya dirasakan saat pengguna berada di dalam kampus, tetapi saat pengguna berada di luar lingkungan kampus. Bangunan kampus yang cenderung memiliki sejumlah gedung yang senantiasa berkaitan fungsi, membuat pengguna kampus harus melakukan mobilitas dari gedung satu menuju gedung lainnya. Mobilitas ini menuntut lingkungan luar kampus dapat memberikan kenyamanan kepada pengguna kampus. Namun, umumnya kenyamanan fasilitas kampus dominan dirasakan di dalam bangunan kampus, sementara lingkungan kampus kurang terarah. Kurang terarahnya lingkungan antar bangunan kampus menyebabkan sejumlah kemungkinan ketidaknyamanan dalam mobilitas dengan berjalan kaki seperti laju aliran udara yang tinggi ((Tisnaningtyas, 2015), memiliki jarak waktu fluktuatif yang berdekatan antara laju aliran udara (Szucs, 2013) dan laju aliran udara yang dapat membawa polutan (Scorer, 1968). Laju aliran tinggi mengganggu aktifitas berjalan sehingga penataan arsitektur dan lansekap di lingkungan antar bangunan kampus menjadi penting untuk meningkatkan kualitas kelaikan fungsi bangunan kampus.

Adapun penelitian yang membahas terkait penataan arsitektur dan lansekap di lingkungan kampus sebagai pengendalian kecepatan angin secara khusus belum ditemukan. Penelitian yang telah dilakukan berkisar pengaruh penataan tapak lingkungan kampus terhadap kenyamanan termal ( Pangestu, dkk. 2009; Sangaji, dkk. 2015; Muhaling, dkk. 2017). Selain itu penelitian kecepatan angin telah dilakukan dalam lingkup pengaruh kecepatan angin dalam bangunan (Amos, dkk. 2014; Turkbeyley, 2012; Baharuddin, 2015; Susanto, dkk. 2015) serta kecepatan angin di ruang luar iklim tropis lembab (Sangkertadi, 2013; Yang, dkk. 2018) dan lingkup urban (Kinvanc, dkk. 2016; Szucs, 2013).

Dalam menciptakan sarana infrastruktur kampus yang laik, perencana saat ini menggunakan berbagai sistem teknologi untuk mengetahui permasalahan kebutuhan infrastruktur, faktor-faktor permasalahan, alternative desain hingga kebutuhan lansekap. Selain itu teknologi juga berguna untuk menampilkan data yang mudah dipahami awam terkait situasi yang terjadi pada bangunan sehingga dapat memberikan upaya perbaikan dan peningkatan mutu infrastruktur kampus. Salah satu teknologi yang banyak digunakan perencana adalah penggunaan Software ENVI-met dan Leonardo. ENVI-met merupakan sebuah software berbasis simulasi angka beresolusi tinggi yang digunakan pada lingkungan urban dengan pendekatan termodinamika, simulasi fluida dan psikologi pohon (ENVI, 2017). ENVI-met banyak digunakan oleh peneliti untuk melakukan simulasi kondisi lingkungan outdoor (Bande, dkk.2019; Elwy, dkk. 2018; Ozkeresteci, dkk., 2013). Disamping itu berdasarkan hasil penelitian Bande 
(2019), software ENVI-met dibandingkan software lainnya memiliki nilai simulasi margin error dengan kondisi lapangan ketika diukur di iklim panas yaitu $1.5^{\circ} \mathrm{c}$, sementara di iklim dingin margin error cukup tinggi. Namun, lingkungan penelitian berada di iklim panas lembab yang mana dapat mengoptimalkan fungsi simulasi ENVI-met dengan baik. Tujuan penelitian ini adalah melakukan penataan lingkungan kampus untuk meningkatkan kenyamana lingkungan khususnya terkait kecepatan angin, dengan menggunakan hasil evaluasi permasalahan menggunakan simulasi dari Software ENVI-met.

\section{Lokasi dan Waktu Penelitian}

\section{METODE PENELITIAN}

Penelitian dilakukan di lokasi Kampus 1 Universitas 'Aisyiyah Yogyakarta. Lingkungan lokasi yang menjadi fokus penelitian adalah area luar lingkungan antara gedung kampus. Dimana batas lokasi penelitian sebelah timur adalah perbatasan Jalan Ringroad barat dengan Kampus UNISA, sebelah barat adalah jalan menuju parkir barat Kampus UNISA, sebelah utara adalah Jalan Pundung dan sebelah selatan adalah lahan bangunan gudang perusahaan. Adapun waktu penelitan untuk simulasi kondisi lingkungan menggunakan software ENVI-met menyesuaikan jam kerja, yaitu pukul $08.00-16.00$.

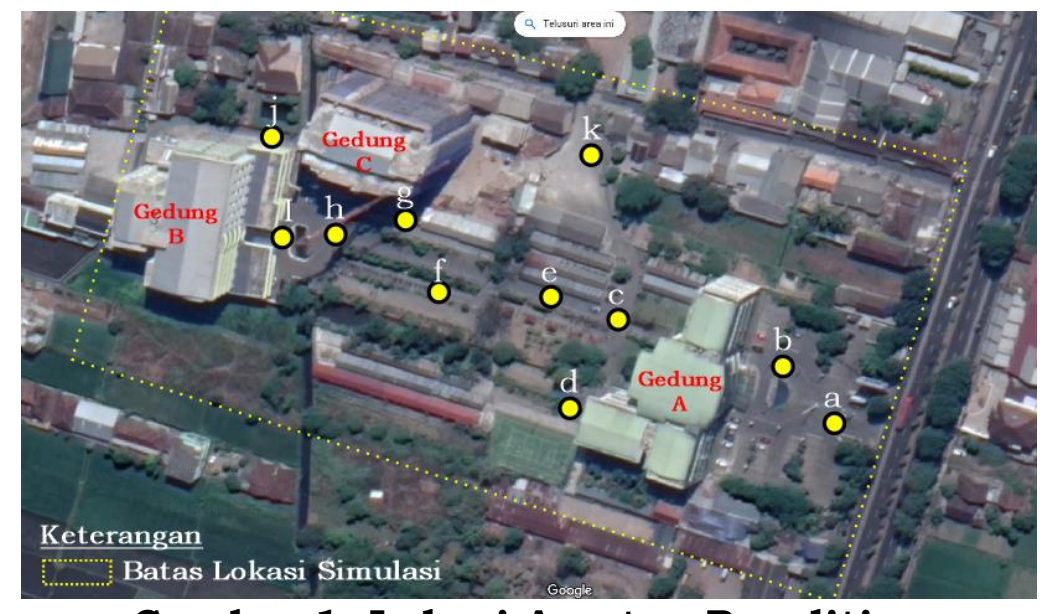

Gambar.1. Lokasi Amatan Penelitian Sumber: Analisis Penulis

\section{Sumber Data}

Sumber data penelitian ini terbagi menjadi dua yaitu data sekunder dan data primer. Data sekunder menggunakan data DED, website BMKG, referensi tertulis dan foto. DED (Detail Engineering Drawing) sebagai acuan modeling terkait ukuran lingkungan dan bangunan. Website BMKG (2020) terkait data cuaca dan arah angin. Referensi tertulis berupa buku referensi dan jurnal ilmiah sebagai background knowledge terkait angin, sifat angin dan kecepatan angin. Sedangkan foto yang digunakan adalah foto kondisi lapangan untuk memperlihatkan material penutup permukaan lingkungan dan jenis vegetasi lingkungan. Adapun data primer untuk data penelitan awal yang bertujuan menggali permasalahan lingkungan kampus, berupa data simulasi menggunakan LEONARDO ENVI-met versi 4.4.5. Lalu referensi tertulis berupa buku referensi, jurnal ilmiah, proseding sebagai 
data studi literatur terkait penataan arsitektur dan lansekap di lingkungan kampus dalam upaya pengkondisian kecepatan udara yang nyaman.

\section{Teknik Pengumpulan Data}

Adapun teknik pengumpulan data awal penelitian adalah dengan teknik pengukuran di lapangan menggunakan alat Envirometer, alat tulis beserta jam (gambar 2.). Selanjutnya dilakukan pengumpulan data sekunder untuk membantu proses modeling dan simulasi menggunakan teknik observasi dengan alat kamera dan alat tulis. Lalu pengumpulan data dengan simulasi menggunakan software LEONARDO ENVI-met. Setelah itu dilakukan pengumpulan data dengan teknik studi literatur.

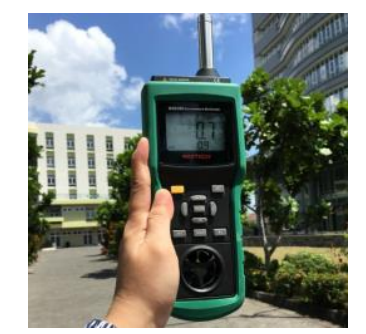

\section{Gambar.2. Alat Enviro sebagai Alat Ukur Kecepatan Angin Lapangan Sumber: Penulis}

\section{Analisis Data}

Analisis data dilakukan secara deskriptif dengan mengkaji literatur (literature review) terkait penataan lingkungan dengan elemen arsitektur dan lansekap, setelah mendapat data permasalahan kenyamanan yang berkaitan dengan kecepatan angin rata-rata menggunakan simulasi software ENVI-met di lokasi penelitian. Hasil analisis data disajikan secara tertulis. Hasil akhir berupa kesimpulan permasalahan yang dapat terjadi di lingkungan kampus beserta metode penataan lingkungan antar bangunan kampus.

\section{HASIL DAN PEMBAHASAN}

Adapun hasil simulasi kecepatan angin rata-rata menggunakan LEONARDO ENVI-met untuk lingkungan kampus UNISA Yogyakarta tanggal 17 September 2020 mulai jam 09.00 sampai jam 16.00 ditunjukan pada tabel 1. Hasil simulasi lingkungan kampus 1 UNISA Yogyakarta menunjukan secara umum lingkungan antar bangunan kampus memiliki rentang kecepatan angin rata-rata dari $0.21 \mathrm{~m} / \mathrm{s}$ hingga diatas $1.90 \mathrm{~m} / \mathrm{s}$. Hal tersebut menunjukan lokasi menurut Beaufort Scale (1805) tergolong dalam level udara ringan (light air). Namun, berdasarkan ASHRAE (2017) tentang kondisi kenyamanan termal lingkungan, suhu di atas 250C, batas kecepatan udara rata-rata adalah $0.8 \mathrm{~m} / \mathrm{s}$. 
Jurnal Arsitektur dan Perencanaan (JUARA)

Hal. 139-152: ISSN Online: 2620-9896

Vol 3, No 2 (2020): September (Jurnal Arsitektur dan Perencanaan

Tabel 1. Hasil Simulasi Kecepatan Angin Rata-Rata Lokasi Penelitian

Hasil Simulasi Kecepatan Angin Rata-Rata

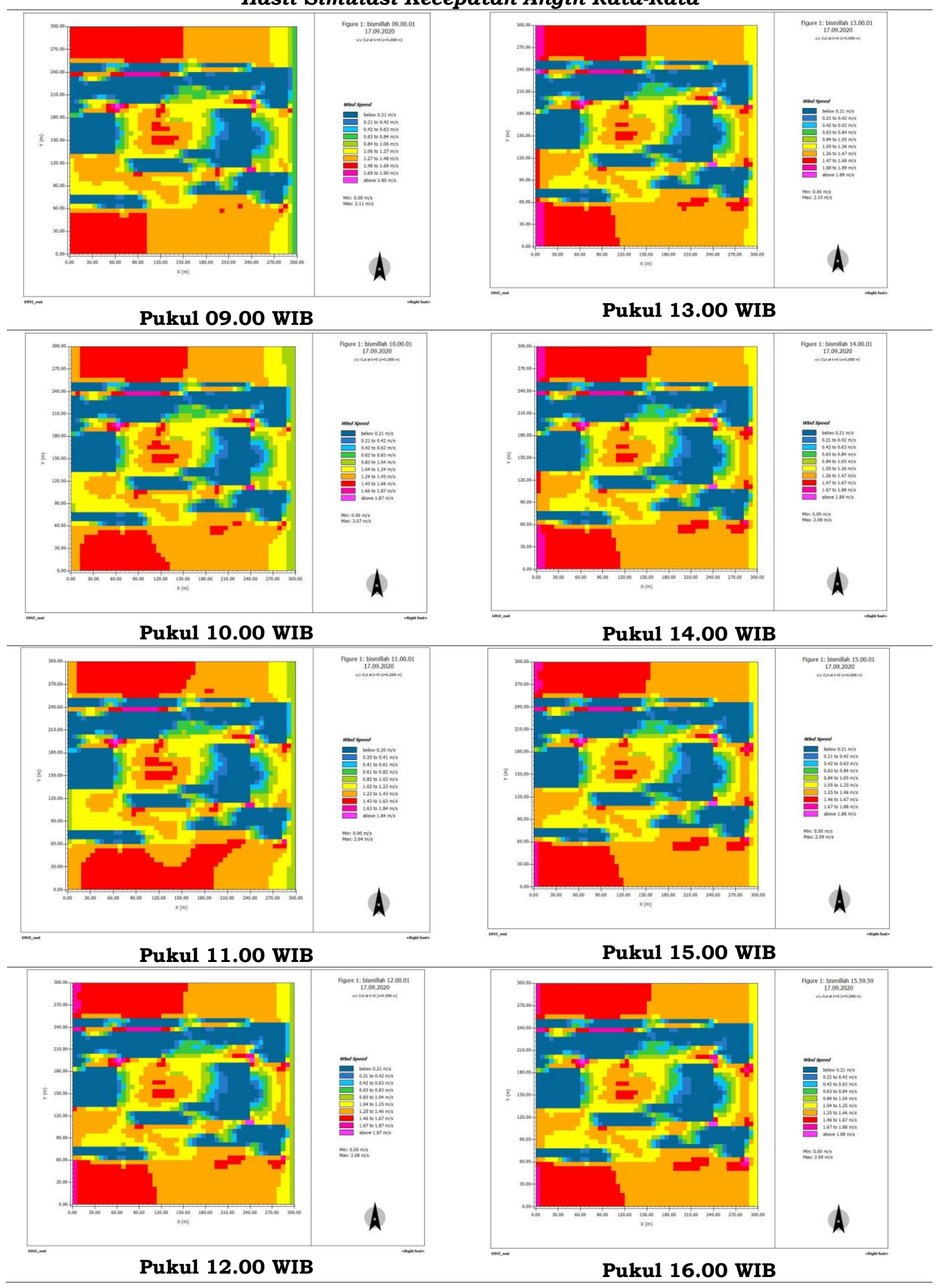


Hal ini menunjukan terdapat kondisi dimana, situasi angin di lingkungan Kampus 1 UNISA Yogyakarta memiliki beberapa titik yang kurang nyaman. Berdasarkan lokasi amatan yang dapat dilihat pada gambar 1., berikut tabel 2. Terkait kelompok kecepatan rata-rata angin yang terjadi.

Tabel 2. Kelompok Kecepatan Angin Rata-rata di Titik Amatan

\begin{tabular}{ccccccccc}
\hline Lokasi & \multicolumn{7}{c}{ Waktu } \\
\cline { 2 - 9 } & $\mathbf{9 . 0 0}$ & $\mathbf{1 0 . 0 0}$ & $\mathbf{1 1 . 0 0}$ & $\mathbf{1 2 . 0 0}$ & $\mathbf{1 3 . 0 0}$ & $\mathbf{1 4 . 0 0}$ & $\mathbf{1 5 . 0 0}$ & $\mathbf{1 6 . 0 0}$ \\
\hline $\boldsymbol{a}$ & 6 & 6 & 6 & 7 & 7 & 7 & 7 & 7 \\
\hline $\boldsymbol{b}$ & 5 & 5 & 4 & 4 & 4 & 4 & 4 & 4 \\
\hline $\boldsymbol{c}$ & 6 & 6 & 6 & 6 & 6 & 6 & 6 & 5 \\
\hline $\boldsymbol{d}$ & 2 & 2 & 2 & 2 & 2 & 2 & 2 & 2 \\
\hline $\boldsymbol{f}$ & 7 & 7 & 8 & 7 & 7 & 7 & 7 & 7 \\
\hline $\boldsymbol{g}$ & 8 & 8 & 8 & 8 & 8 & 8 & 8 & 8 \\
\hline $\boldsymbol{h}$ & 8 & 8 & 8 & 8 & 8 & 8 & 8 & 8 \\
\hline $\boldsymbol{j}$ & 7 & 7 & 7 & 7 & 7 & 7 & 7 & 7 \\
\hline $\boldsymbol{k}$ & 6 & 3 & 3 & 3 & 3 & 3 & 3 & 3 \\
\hline
\end{tabular}

Adapun kelompok kecepatan angin rata-rata tersebut adalah 1 (dibawah $0.21 \mathrm{~m} / \mathrm{s}, 2(0.21-0.42 \mathrm{~m} / \mathrm{s}, 3(0.42-0.63) \mathrm{m} / \mathrm{s}, 4(0.63-0.84)$ $\mathrm{m} / \mathrm{s}, 5(0.84-1.06) \mathrm{m} / \mathrm{s}, 6(1.06-1.27) \mathrm{m} / \mathrm{s}, 71.27-1.48 \mathrm{~m} / \mathrm{s}, 81.48-1.69$ $\mathrm{m} / \mathrm{s}, 91.69-1.90 \mathrm{~m} / \mathrm{s}, 10$ diatas $1.90 \mathrm{~m} / \mathrm{s}$. Sehingga berdasarkan sebelas lokasi yang menjadi titik amatan terdapat delapan lokasi yang belum memenuhi standar kenyamanan termal ASHRAE (2017) yaitu lokasi a, c, e, $\mathrm{f}, \mathrm{g}, \mathrm{h}, \mathrm{j}$ dan $\mathrm{k}$. Hal ini menunjukan lingkungan antar bangunan Kampus masih didominasi oleh kecepatan angin yang terkategori tidak nyaman untuk pengguna. Kategori tidak nyaman tersebut, dimana lokasi memiliki kecepatan angin yang lebih tinggi dari kondisi nyaman $(0.80 \mathrm{~m} / \mathrm{s})$

Lokasi $\mathrm{b}$ berdasarkan jam amatan mengalami pergeseran kecepatan angin rata-rata yang semula tidak nyaman, dimulai pukul 11.00 wib masuk ke dalam kelompok nyaman. Sementara di lokasi a, setelah melewati pukul 12.00 mengalami kenaikan kecepatan angin rata-rata. Lokasi e hanya di jam tertentu mengalami kenaikan, lalu kembali ke kecepatan angin ratarata semula. Berdasarkan Nasrullah (2015) menyebutkan bahwa di kondisi iklim tropis lembab kondisi temperatur udara tertinggi terjadi sekitar dua jam sebelum cahaya jatuh tegak lurus dan dua jam setelahnya atau sekitar pukul 10.00 hingga 14.00. Sementara temperatur udara dapat mempengaruhi timbulnya pergerakan angin (Thangprasert, N., dkk. 2017) khususnya di daerah yang dekat dengan permukaan. Temperatur Atsmosfir sangat mempengaruhi tekanan udara, yang mana tekanan udara mempengaruhi pergerakan angin (Wooten, 2011). Perubahan yang terjadi pada kondisi a,b dan e mulai perubahan disekitar jam 11 dan 12. Hal ini menunjukan kecepatan angin rata-rata di lokasi dapat dipengaruhi juga oleh kondisi pergeseran matahari. 


\section{Permasalahan Peningkatan Kecepatan Angin Rata-rata}

Adapun berdasarkan elemen arsitektur dan lansekap juga berpengaruh terhadap laju kecepatan angin rata-rata. Sehingga dengan melakukan penataan elemen arsitektur dan lansekap dapat mengkondisikan kecepatan angin rata-rata dari kondisi tidak nyaman menjadi nyaman. Elemen arsitektural dapat meliputi penataan orientasi bangunan (Pangestu, 2017), bentuk bangunan (Pangestu, 2017; Kinvanc,2016), ruang terbuka (Amin, 2017), koridor (Kinvanc,2016), dekorasi arsitektur (Pangestu, 2009; Kinvanc, 2016), naungan (Sangkertadi, 2013), desain pagar (Amos, 2014) dan elemen lansekap meliputi pemilihan jenis vegetasi (Kinvanc, 2016), penambahan vegetasi , tata letak vegetasi, pengolahan permukaan tanah (Pangestu, 2009; Kinvanc,2016; Amos, 2014). Tabel 3. Menjelaskan terkait kondisi lingkungan eksisting dan solusi penataan.

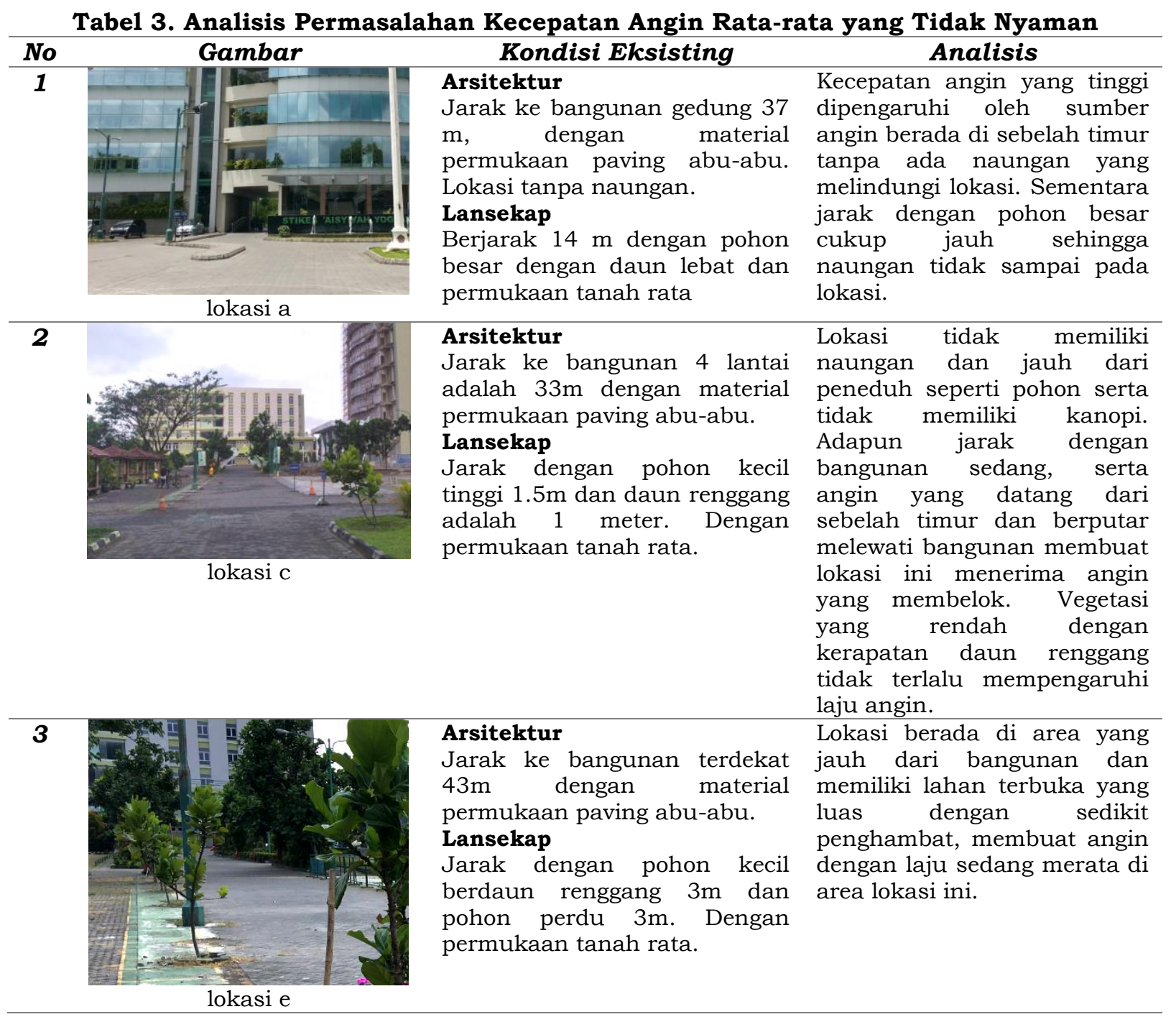




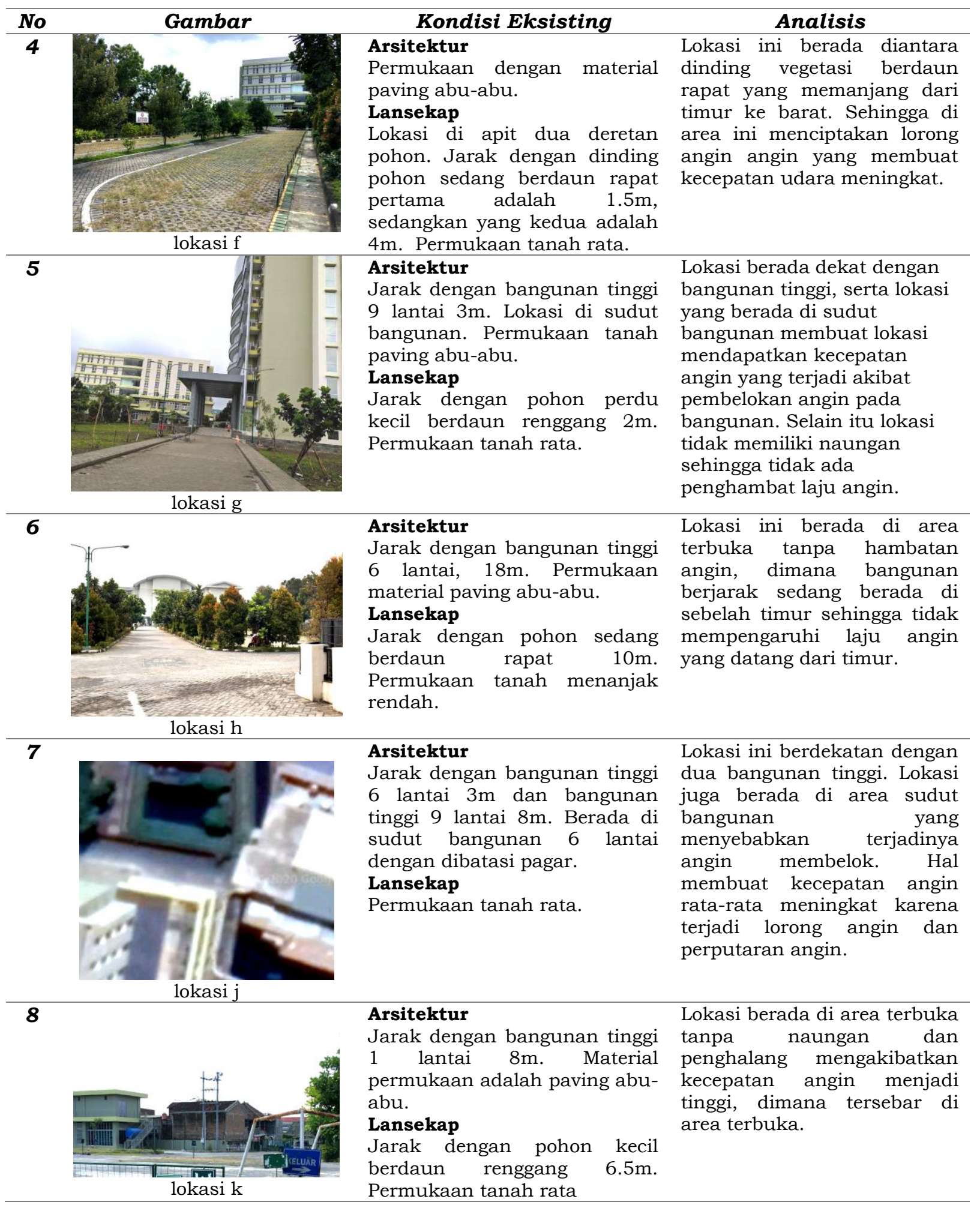

Berdasarkan tabel 3. Dapat disimpulkan permasalahan kecepatan angin rata-rata di atas standar kenyamanan termal untuk pengguna di lingkungan antar bangunan Kampus UNISA Yogyakarta adalah pertama (lokasi a, c, e, h, k), lokasi berada di area terbuka. Hal ini sejalan dengan penelitikan Amin, dkk (2017) dimana area terbuka dapat mengalirkan angin dengan baik. Selain itu angin yang berada di area permukaan terbuka dibandingkan area yang padat bangunan memiliki tingkat kecepatan angin 
yang tinggi seperti area pedesaan yang kecepatan angin lebih tinggi dibandingkan area perkotaan (Kinvanc,dkk., 2016) karena area tidak memiliki penghambat angin. Kedua (lokasi g dan j), lokasi untuk pejalan kaki berada di lokasi area sekitar sudut bangunan. Lokasi tersebut memiliki kecepatan angin yang tinggi karena terjadi angin mengalami respon dinamik, yang mana angin timbul sebagai gerakan searah angin dan gerakan searah anging, gerakan ke samping dan gerakan memutar (Fariduzzaman, 2016). Diakibatkan angin mencari jalan untuk bergerak. Lokasi yang tanpa naungan atau penghalang angin mengakibatkan angin yang membelok tidak terhalangi dan tetap melaju (gambar 3a.). Ketiga (lokasi f), angin yang terjadi karena lorong angin. Lorong angin terjadi akibat angin yang semula berasal dari area terbuka masuk ke area yang memiliki batasan disekelilingnya, hal ini mengakibatkan daya hisap angin (Susanto, 2015), dimana area yang dibatasi tersebut menyalurkan angin lebih cepat. Selain itu berdasarkan Michelle (2011), tanaman/vegetasi rapat yang berbaris membentuk dinding diantara kedua jalan memiliki efek negatif membentuk wind tunnel/ lorong angin (gambar 3b.). Keempat (lokasi $\mathrm{f}, \mathrm{g}, \mathrm{j})$, angin yang terjadi karena defleksi aliran angin. Angin yang mengalir mengenai penghalang yang cukup tinggi, maka angin tersebut dibelokan menuju tanah (Fariduzzaman, 2016), menyebabkan kecepatan angin ratarata, area dekat permukaan tanah meningkat (gambar 3c.). Angin yang dibelokan ke tanah adalah angin dengan kecepatan yang tinggi di bagian atas sehingga hal ini dapat mengganggu aktifitas berjalan pejalan kaki (Dyrbye, 1997).
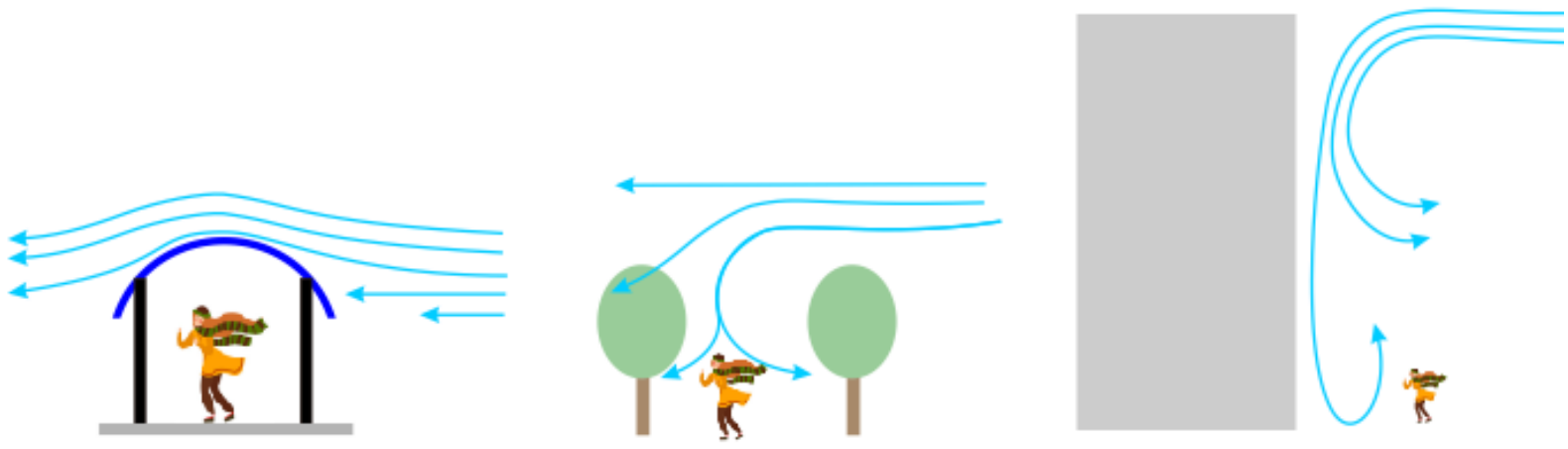

\section{Gambar.3. (a)Naungan sebagai Penghalang Angin, (b)Lorong angin, (c) Defleksi Angin karena Bangunan Tinggi Sumber: Analisis Penulis}

\section{Penataan Lingkungan Antar Bangunan Kampus untuk Menenurunkan Kecepatan Angin Rata-rata}

Berdasarkan ke empat permasalahan yang terjadi di area lingkungan Kampus UNISA Yogyakarta, dimana lokasi yang dipilih digunakan sebagai area jalan pengguna kampus untuk mencapai bangunan satu dengan bangunan lain sehingga diperlukan penataan untuk meningkatkan kenyamanan pengguna khususnya terhadap kecepatan angin rata-rata yang terjadi. Adapun penataan dilihat dari elemen arsitektur dan lansekap, yang mana elemen tersebut mempengaruhi kecepatan angin rata-rata. Sehingga dengan melakukan penataan elemen arsitektur dan lansekap dapat mengkondisikan kecepatan angin rata-rata dari kondisi tidak nyaman 
Jurnal Arsitektur dan Perencanaan (JUARA)

Hal. 139-152: ISSN Online: 2620-9896

Vol 3, No 2 (2020): September (Jurnal Arsitektur dan Perencanaan

menjadi nyaman. Elemen arsitektural dapat meliputi penataan orientasi bangunan (Pangestu, 2017), bentuk bangunan (Pangestu, 2017; Kinvanc,2016), ruang terbuka (Amin, 2017), koridor (Kinvanc,2016), dekorasi arsitektur (Pangestu, 2009; Kinvanc, 2016), naungan (Sangkertadi, 2013), desain pagar (Amos, 2014). Sedangkan elemen lansekap meliputi pemilihan jenis vegetasi (Kinvanc, 2016), penambahan vegetasi , tata letak vegetasi, pengolahan permukaan tanah (Pangestu, 2009; Kinvanc,2016; Amos, 2014).

Permasalahan pertama adalah lokasi yang berada di area terbuka menyebabkan angin dapat melaju tanpa penghalang. Kondisi ini dapat dilakukan penataan lansekap dengan memberikan penghalang angin berupa vegetasi, vegetasi dinilai efektif sebagai penghalang untuk mengurangi laju angin (Amos, dkk.,2014). Adapun jenis vegetasi yang efektif mengurangi laju angin adalah pohon yang memiliki ukuran lebih tinggi dari manusia (Kinvanc, dkk., 2016) dan daun rapat (Szucs, dkk., 2013). Ukuran vegetasi yang efektif untuk mengurangi laju adalah vegetasi dengan tinggi 2m (Szucs, dkk., 2013). Namun, penyusunan pohon di desain tidak terlalu rapat dan masih memiliki jarak, sehingga tanaman masih mampu menyalurkan angin dan membuat perlambatan laju angin. Pohon yang terlalu rapat membuat angin yang tertahan diantara pohon dapat meningkatkan angka kecepatan angin di sekitar pohon karena pohon bertindak sebagai penghalang. Selain itu penataan lansekap di area terbuka juga dapat dilakukan dengan memberikan perbedaan ketinggian atau kontur yang bergelombang pada permukaan area berjalan kaki. Permukaan yang kasar mampu mengurangi kecepatan angin dibandingkan permukaan yang datar (Kinvanc, dkk., 2016; I.Umut, 2008). Sedangkan Penataan di lingkungan Kampus UNISA Yogyakarta pada elemen arsitektur dapat menggunakan naungan seperti kanopi atau atap teduhan untuk pejalan kaki di lingkungan kampus. Naungan membantu mengurangi laju angin yang cukup tinggi (Sangkertadi, 2013).

Permasalahan kedua, dimana area pejalan kaki berada di sudut bangunan. Penataan lokasi menggunakan elemen vegetasi, dengan membuat penghalang vegetasi menggunakan pohon berdaun rimbun yang ditempatkan di sekitar sudut arah angin datang atau pada kasus di timur. Untuk membelokan angin yang datang atau memperkecil laju dari angin yang datang seperti pada penelitian Kinvanc (2016) penggunaan pepohonan di area sudut daerah perkotaan dapat memberikan angin yang lembut ke dalam perkotaan. Penataan lingkungan dengan elemen arsitektur seperti penggunaan pagar perforasi/berlubang di lokasi sudut dengan jarak tidak terlalu jauh dan tidak terlalu dekat dari bangunan (Amos, dkk.,2014). Pagar ini berguna untuk mengurangi kecepatan angin yang berada di lingkung area pejalan kaki. Penataan elemen arsitektur juga dapat dilakukan dengan pembuatan sirip-sirip horizontal pada bangunan untuk menyebarkan angin sehingga kecepatan angin berkurang (Pengestu, dkk.,2009). Penggunaan naungan atau kanopi di area pejalan kaki di sekitar sudut bangunan juga dapat mengurangi kecepatan angin di lokasi tersebut (Sangkertadi, 2013).

Permasalahan ketiga, kecepatan angin yang meningkat dikarenakan vegetasi terlalu rapat dapat dilakukan dengan penataan elemen lansekap dengan pemilihan vegetasi pohon yang lebih kecil atau memiliki porositas vegetasi lebih besar dari 40\%, dan dapat juga pemilihan pohon dengan 
Jurnal Arsitektur dan Perencanaan (JUARA)

Hal. 139-152: ISSN Online: 2620-9896

Vol 3, No 2 (2020): September (Jurnal Arsitektur dan Perencanaan

bentuk kanopi terbuka. Pohon berbentuk cemara bekerja paling baik dibandingkan tanaman daun untuk mengurangi kecepatan angin dan polusi. Namun, jika pohon digunakan untuk penghalang angin, pohon dipilih yang memiliki daun dengan porositas kurang dari $30 \%$ sehingga memaksimalkan pohon untuk menghalangi angin. Selain itu untuk memaksimalkan pohon sebagai penghalang pohon disusun lebih rapat, lebih kecil dari lebar tajuk pohon. Serta peletakan pohon sebaiknya membentuk 90o berbaris terhadap datangnya arah angin sehingga angin dapat menghantam tegak lurus dan kembali ke permukaan setelah bergerak 10-15 kali tinggi penghalang dengan kecepatan yang lebih lambat (Michelle, 2011).

Permasalahan keempat angin yang terjadi karena defleksi dari penghalang yang cukup tinggi seperti bangunan gedung menuju permukaan tanah (Fariduzzaman, 2016). Permasalahan ini dapat diatur dengan penataan elemen arsitektur berupa penambahan sirip horizontal pada fasad bangunan (Pengestu, dkk.,2009).

Tabel 4. Penataan Lokasi Berdasarkan Studi Literatur

\begin{tabular}{|c|c|c|c|}
\hline No & Lokasi & Arsitektur & Lansekap \\
\hline 1 & Di area terbuka & $\begin{array}{l}\text { - Penggunaan naungan atau } \\
\text { kanopi di area pejalan kaki }\end{array}$ & 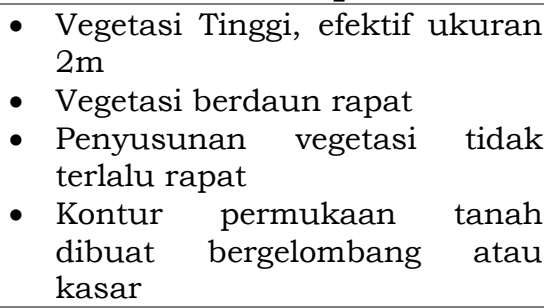 \\
\hline 2 & Di sudut bangunan & $\begin{array}{l}\text { - Penggunaan pagar berlubang } \\
\text { (perforasi wall di area yang } \\
\text { tidak terlalu jauh dari jalur } \\
\text { pejalan kaki } \\
\text { - Penggunaan sirip-sirip } \\
\text { horizontal pada bangunan } \\
\text { - Penggunaan naungan atau } \\
\text { kanopi pada area pejalan kaki }\end{array}$ & $\begin{array}{l}\text { - Penggunaan vegetasi/ pohon } \\
\text { rimbun di area sekitar sudut } \\
\text { bangunan khususnya dari } \\
\text { arah yang menerima angin }\end{array}$ \\
\hline 3 & $\begin{array}{lr}\text { Di lorong } & \text { angin } \\
\text { akibat } & \text { vegetasi } \\
\text { terlalu rapat } & \end{array}$ & & $\begin{array}{l}\text { - Pemilihan jenis pohon berdaun } \\
\text { dengan porositas lebih tinggi } \\
\text { dari 40\% untuk menghindari } \\
\text { lorong angin } \\
\text { - Pemilhan vegetasi dengan } \\
\text { kanopi terbuka seperti cemara } \\
\text { - Pemilihan pohon berdaun } \\
\text { dengan kerapatan kurang dari } \\
30 \% \text { untuk memaksimalkan } \\
\text { pohon sebagai penghalang } \\
\text { angin secara maksimal } \\
\text { - Peletakan pohon dengan posisi } \\
\text { 90 dari arah datang angin } \\
\text { - Penyusunan pohon berdaun } \\
\text { lebat dengan jarak antar pohon } \\
\text { yang rapat kurang dari lebar } \\
\text { tajuk pohon }\end{array}$ \\
\hline 4 & $\begin{array}{l}\text { Defleksi angin } \\
\text { bangunan tinggi }\end{array}$ & 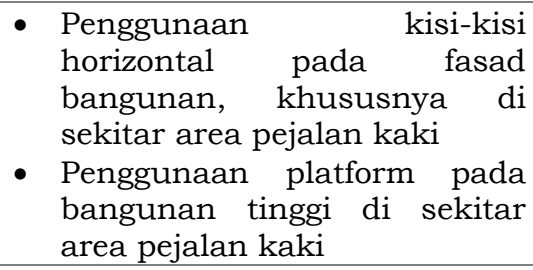 & \\
\hline
\end{tabular}


Jurnal Arsitektur dan Perencanaan (JUARA)

Hal. 139-152: ISSN Online: 2620-9896

Vol 3, No 2 (2020): September (Jurnal Arsitektur dan Perencanaan

Selain itu pemasangan platform pada bangunan bertingkat tinggi seperti bangunan c dengan 9 lantai (Kinvanc, 2016) dapat merubah laju angin Hal tersebut juga digunakan oleh penelitian Kinvanc (2016) yang menggunakan platform pada bangunan bertingkat untuk mengurangi laju angin. Adapun kesimpulan penataan untuk mengurangi kecepatan angin berdasarkan studi literatur ditunjukan tabel 4 tersebut.

\section{SIMPULAN DAN SARAN}

Penataan lingkungan antar bangunan kampus dibutuhkan untuk meningkatkan kenyamanan pengguna khususnya saat melakukan mobilisasi dari satu bangunan ke bangunan kampus lainnya. Kenyamanan salah satunya adalah pengkondisian kecepatan udara sehingga tidak menganggu pengguna lingkungan bahkan tidak menjadi perantara pembawa polutan. Permasalahan kecepatan angin dapat terjadi karena terjadinya pergeseran waktu. Adapun permasalahan kecepatan angin yang lebih tinggi dari standar kenyamanan di lingkungan kampus (lokasi penelitian, Kampus 1 UNISA Yogyakarta) terjadi karena penataan arsitektur dan lansekap yang kurang maksimal, Permasalahan tersebut dijabarkan dalam empat hal. Keempat hal tersebut yaitu lokasi yang berada di area terbuka, lokasi yang berada di sudut bangunan, lokasi yang berada di lorong angin dan lokasi yang berada di area yang terkena dampak dari defleksi angin oleh bangunan tinggi. Adapun penataan berdasarkan studi literatur dapat dilakukan dengan penataan elemen arsitektur dan elemen lansekap untuk mengurangi kecepatan angin. Penataan elemen arsitektur di lingkungan kampus yang digunakan pengguna khususnya untuk mobilitas yaitu penggunaan naungan/kanopi, penggunaan pagar berlubang, penggunaan sirip-sirip horizontal pada fasad bangunan dan penggunaan platform pada bangunan tinggi. Sedangkan penataan elemen lansekap di lingkungan kampus yaitu penggunaan vegetasi khususnya jenis pohon berdaun rapat atau renggang tergantung kebutuhan sebagai perlambat atau penghalang angin. Vegetasi minimal tinggi $2 \mathrm{~m}$ dengan pola susun yang tidak terlalu rapat. Vegetasi dapat diletakan di area datangnya angin. Adapun permukaan tanah dapat dibuat bergelombang atau berkontur.

\section{DAFTAR RUJUKAN}

Dyrbye,C. \&Hnsen,S.O. 1997. Wind Loads on Structures. John Wiley \& Sons, Chichester.

Lechner, N. 2007. Heating Cooling Lighting Metode Desain untuk Arsitektur. Jakarta (ID): Pt. Raja Grafindo Persada

Scorer, R. 1968. Air Pollution. Oxford: Pergamon Press.

de Roo, Michelle. 2011. The Green City Guidelines, Techniques for a healthy liveable city. The Green City ISBN 978-94-91127-00-7. 
Jurnal Arsitektur dan Perencanaan (JUARA)

Hal. 139-152: ISSN Online: 2620-9896

Vol 3, No 2 (2020): September (Jurnal Arsitektur dan Perencanaan

Amin, A.R.Z. 2017. Studi Penghawaan Alami pada Bangunan Sekolah Dasar di Pinggiran Sungai Musi Plembang. Jurnal Arsir Universitas Muhammadiyah Palembang Volume 1 (2) 2017: 86-99

Amos, Abanyie S., Koranteng, C., Apeatse, K.E. 2014. An Evaluation of The Effects of External Landscaping Elements on Indooe Airflow Rate and Patterns Using Computational Fluid Dynamics. European Scientific Journal, Volume 10 (14) 2014: 286 - 299

Bande, L., Afshari, A., Al Masri, D., Jha, M., Norford, L., Tsoupos, A., Marpu, P., Pasha, Y., Armstrong, P. 2019. Validation of UWG and ENVI-Met Models in an Abu Dhabi District, Based on Site Measurements. Sustainability (11), 4378: 1-20

Elwy, I., Ibrahim, Y., Fahmy, M., Mahdy M 2018. Outdoor microclimatic validation for hybrid simulation workflow in hot arid climates against ENVI-met and field measurement. Energy Procedia 153,2018: 29-34.

Fariduzzaman. 2016. Uji Pergerakan Angin di Sekitar Model Gedung dengan Terowongan Angin. Jurnal Teknologi Lingkungan Volume 17 (2) 2016: 82-91

Kinvanc, Ak., Ozdede, Sinem. 2016. Urban Landscape design and planning related to wind effects. Oxidation Communications 39 (I-II): 699-710

Pangestu, Setiawan,M.D. 2009. Pengaruh Penataan Tapak terhadap Kenyamanan Termal di Ruang Luar Bangunan Rektorat Universitas Katolik Parahyangan Bandung. Repository Universitas Katolik Parahyangan.

Sangkertadi. 2013. Pengaruh Kecepatan Angin terhadap Tingkat Kenyamanan Termal di Ruang Luar Iklim Tropis Lembab. Jurnal Lingkungan Binaan Indonesia Volume 2 (1) 2013: 26-34

Susanto, J., Dafik, Arif. 2015. Analisis Kecepatan Aliran Udara pada Gedung Bertingkat karena Pengaruh Penghalang di Depannya. Kadikma Volume 6(2) 2015: 75-82

Szucs, Agota. 2013. Wind Comfort in a Public Urban Space-Case Study Within Dublin Docklands. Frontier of Architectural Research (2) 2013: 50-66

Thangprasert, N., Suwanarat, S.2017. The Relationships between Wind Speed and Temperature Time Series in Bangkok, Thailand. Journal of Physics 901, 2017

Tisnaningtyas, E.Y. 2015. Aspek Kenyamanan Pejalan Kaki terhadap Iklim Tropis dan Aksesibilitas Pejalan Kaki di Lapangan Kota sebagai Kawasan Pedestrian (Kajian Kawasan Simpang Lima Semarang). Jurnal Unpand, 2015: 54-62

Wooten, R.D.2011. Statistical Analysis of the relationship between wind speed, pressure and temperature. Journal of Applied Sciences, 2011 
Jurnal Arsitektur dan Perencanaan (JUARA)

Hal. 139-152: ISSN Online: 2620-9896

Vol 3, No 2 (2020): September (Jurnal Arsitektur dan Perencanaan

Yang, Wei., Lin, Yaolin, Qing Li, Chun. 2018. Effects of Landscape Design on Urban Microclimate and Thermal Comfort in Tropical Climate. Advances in Meteorology. Advances in Meteorology, 2018: 1-13

ASHRAE. 2017. ASHRAE Standard 55-2017 Thermal Environmental Conditions for Human Occupancy. ANSI.

ENVI-MET. 2017. Decoding Urban Nature. ENVI.

PDDikti. 2018. Statistik Pendidikan Tinggi. RISTEKDIKTI

PermenPU. 2007. Peraturan Menteri Pekerjaan Umum No.25/PRT/M/2007 tentang Pedoman Sertifikat Laik Fungsi Bangunan Gedung. Indonesia: Kementerian Pekerjaan Umum

I. UMUT. 2008. The Methods Used in the Transformation of Renewable Energy Sources into Electricity and Sample Applications. Tesis Diterbitkan. Turki: Universitas Trakya

Baharuddin, Ishak, M.T., Asniawaty. 2015. Pengaruh Kecepatan Aliran Udara Terhadap Tingkat Kenyamanan Termal di Ruang Kuliah. Proseding Seminar Ilmiah Nasional (1),2015: 1-8

Nasrullah, Rahim, R., Baharuddin, Mulyadi, R., Jamala, N., Kusno, A. 2015. Temperatur dan Kelembaban Relatif Udara Outdoor. (Online) Temu Ilmiah IPLBI1QZ, (https://temuilmiah.iplbi.or.id)

Ozkeresteci, I., Crewe, K., Brazel, A.J., Bruse, M. 2003. Use and Evaluation of The ENVI-met for Environmental Design and Planning: an Experiment on Linear Parks. Proseding Seminar, the $21^{\text {st }}$ International Cartographic Conference (ICC): 402-409

Britain's Admiral Sir Francis Beaufort. 1805. Beaufort Wind Scale. Artikel Project Professional Group Pty.Ltd. (online), (http://www.mackiteboarding.com), diakses 17 September 2020. 